\title{
Infective costochondritis and multiple abscesses in a healthy adult
}

\author{
Naomasa Yoshiyama (1) , Shingo Tsuneyoshi, ${ }^{2}$ Jun-ichiro Nishi, ${ }^{1}$ Hidehiro Ishii ${ }^{2}$
}

${ }^{1}$ Department of Emergency Medicine, Fukuoka-ken Saiseikai Futsukaichi Byoin, Chikushino, Fukuoka, Japan

${ }^{2}$ Department of Internal Medicine, Fukuoka-ken Saiseikai Futsukaichi Byoin, Chikushino, Fukuoka, Japan

\section{Correspondence to}

Dr Naomasa Yoshiyama; night_dreams_of_ophelia@ yahoo.co.jp

Accepted 17 December 2020

\section{DESCRIPTION}

Infective costochondritis is particularly associated with chest wall trauma, postsurgical state, compromised host and intravenous drug abuse. ${ }^{1}$ Differentiating costochondritis with an infection from that without an infection is sometimes difficult. We describe a case of an adult without any medical history who developed infective costochondritis and multiple abscesses.

A 54-year-old woman with a generally good health condition was referred to our hospital due to mild pain in the superior thorax when moving, which was accompanied by a slightly increased temperature over the affected site. The patient's height and weight were $163 \mathrm{~cm}$ and $61 \mathrm{~kg}$, respectively. Physical examination did not reveal any swelling or redness in the pharyngolarynx or the presence of a cervical lymph node, respiratory murmur, palpitation or cold sweat. ECG and thoracic CT did not reveal notable findings. The patient was diagnosed with costochondritis and treated with a single dose of $400 \mathrm{mg}$ acetaminophen. However, after 3 days,

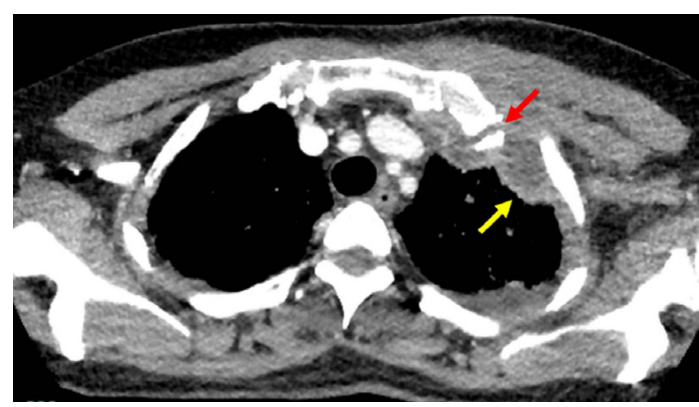

Figure 1 A thoracic CT scan demonstrating an abscess in the left side of the first and second articulatio sternoclavicularis, accompanied by swelling (red arrowhead); in the left side of the chest wall; and in the lung (yellow arrowhead).

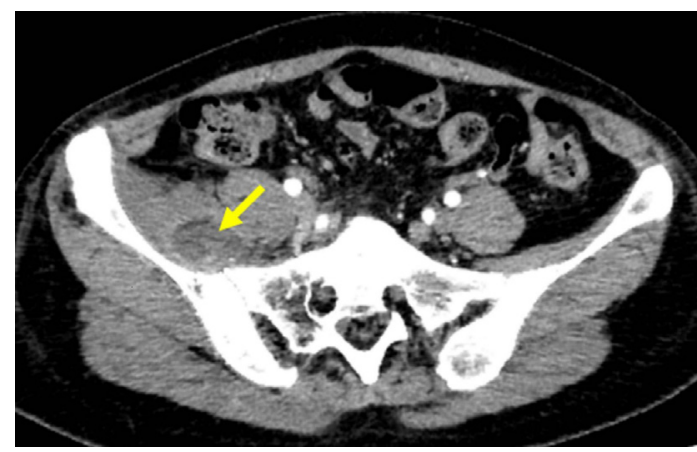

Figure 2 An abdominal CT scan showing an abscess in the right iliopsoas (yellow arrowhead). the intolerable pain spread to the left clavicle, left upper chest and right haunches, which was accompanied by a fever. Thoracic and abdominal CT showed multiple abscesses in the left side of the first and second articulatio sternoclavicularis, left superior chest wall, lung (figure 1) and right iliopsoas (figure 2). The patient was suspected of having bacteraemia and infectious endocarditis, but the echocardiogram findings revealed no vegetation. Performing puncture and drainage of the chest wall and lung abscesses was technically difficult. Thus, on admission, the patient was administered $9 \mathrm{~g} /$ day sulbactam/ampicillin until day 2 of admission. The blood culture was positive for Staphylococcus aureus; thus, $6 \mathrm{~g} /$ day cefamezin and $2000 \mathrm{mg} /$ day cephalexin were administered for 1 month. The patient's clinical course was good, and at 2 months after the disease onset, symptoms of infective costochondritis and multiple abscesses disappeared.

Patients without any medical history can develop infective costochondritis and multiple abscesses. The abscess can expand to other body areas for a few days. The reason why infective costochondritis

\section{Patient's perspective}

I had oppressive pain on the left side of my upper chest, back and neck a few days before admission. The pain location seemed to change daily. I lived in a two-storey house, and I could not go upstairs to my bedroom; thus, I only slept in our living room. On admission, I had a fever and was in great pain. I could not even walk properly or even go to a lavatory. During the first week in the hospital, I felt anxious about my health, future and hospitalisation. However, after my hospitalisation for 1.5 months, I did not have any problem performing my daily living activities. Although I sometimes feel pain, especially in the neck, shoulder and hip areas, I can still perform regular exercises to maintain good health.

\section{Learning points}

- Infective costochondritis and multiple abscesses could occur in patients without any medical history; multiple abscesses can form in several body areas for a few days.

- We should consider the presence of an infection in patients with costochondritis who had not only pain but also mild fatigue or fever; these patients should be carefully observed. 
and multiple abscesses caused by $S$. aureus can occur in healthy patients was unclear. The possible mechanism of $S$. aureus infection is the presence of a hematogenous infection in the pharyngolarynx, even without a cold, ${ }^{2}$ or a cutaneous infection without a history of trauma or atopic dermatitis. ${ }^{3}$ Moreover, a history of unrecognised influenza, a viral infection, could possibly worsen the $S$. aureus infection, leading to the formation of multiple abscesses. ${ }^{4}$

In patients with costochondritis symptoms, such as pain accompanied by mild fatigue and fever, clinicians should consider that they are in an infective state and must carefully be observed. The most common causative organisms of infective costochondritis are $S$. aureus and various Streptococcus species in those without a history of intravenous drug abuse. ${ }^{5}$ The proportion of infective cases caused by community-acquired methicillin-resistant S. aureus has increased. ${ }^{6}$ In this case, the causative agent was methicillin-sensitive S. aureus. However, we should consider the administration of anti-methicillin-resistant $S$. aureus antibiotics initially.

Acknowledgements The authors would like to thank Mr Azusa Hojyo for his technical support in treating the patient.
Contributors NY, ST, JN and HI treated the patient. NY wrote the manuscript. HI supervised this report. All authors have read and approved the final manuscript.

Funding The authors have not declared a specific grant for this research from any funding agency in the public, commercial or not-for-profit sectors.

Competing interests None declared.

Patient consent for publication Obtained.

Provenance and peer review Not commissioned; externally peer reviewed.

\section{ORCID iD}

Naomasa Yoshiyama http://orcid.org/0000-0003-2002-7780

\section{REFERENCES}

1 Proulx AM, Zryd TW. Costochondritis: diagnosis and treatment. Am Fam Physician 2009;80:617-20.

2 Lee CJ, Sankaran S, Mukherjee DV, et al. Staphylococcus aureus oropharyngeal carriage in a prison population. Clin Infect Dis 2011;52:775-8.

3 Faden $\mathrm{H}$, Lesse AJ, Trask J, et al. Importance of colonization site in the current epidemic of staphylococcal skin abscesses. Pediatrics 2010;125:e618-24.

4 Denison AM, Deleon-Carnes M, Blau DM, et al. Molecular characterization of Staphylococcus aureus and influenza virus coinfections in patients with fatal pneumonia. J Clin Microbiol 2013;51:4223-5.

5 Sakran W, Bisharat N. Primary chest wall abscess caused by Escherichia coli costochondritis. Am J Med Sci 2011;342:241-6.

6 Pickett A, Wilkinson M, Menoch $M$, et al. Changing incidence of methicillin-resistant Staphylococcus aureus skin abscesses in a pediatric emergency department. Pediatr Emerg Care 2009;25:831-4.

Copyright 2021 BMJ Publishing Group. All rights reserved. For permission to reuse any of this content visit

https://www.bmj.com/company/products-services/rights-and-licensing/permissions/

BMJ Case Report Fellows may re-use this article for personal use and teaching without any further permission.

Become a Fellow of BMJ Case Reports today and you can:

- Submit as many cases as you like

- Enjoy fast sympathetic peer review and rapid publication of accepted articles

- Access all the published articles

- Re-use any of the published material for personal use and teaching without further permission

\section{Customer Service}

If you have any further queries about your subscription, please contact our customer services team on +44 (0) 2071111105 or via email at support@bmj.com.

Visit casereports.bmj.com for more articles like this and to become a Fellow 